\title{
Comparison of Learning Style for Engineering and Non-Engineering Students
}

\author{
Mimi Mohaffyza ${ }^{1, *}$, Jailani Md Yunos ${ }^{1}$, Yee Mei Heong ${ }^{1}$, Junita $^{1}$, Fahmi Rizal $^{2}$, Badaruddin Ibrahim $^{1}$ \\ ${ }^{1}$ Faculty of Technical and Vocational Education, Universiti Tun Hussein Onn Malaysia, Parit Raja Batu Pahat, 86400, Malaysia \\ ${ }^{2}$ Fakultas Teknik, Universitas Negeri Paandg, Jln Prof Hamka Air Tawar Paandg, Sumatera Barat Paandg, 25131, Indonesia
}

\begin{tabular}{l} 
A R T I C L E I N F O \\
\hline Article history: \\
Received: 31 December, 2020 \\
Accepted: 05 April, 2021 \\
Online: 20 July, 2021 \\
\hline Keywords: \\
Learning styles \\
Accommodator \\
Converger \\
Diverger \\
\end{tabular}

\begin{tabular}{l} 
A B S T R A C T \\
\hline Educators should be considered the learning style of students so that the best practice \\
approach can be applied in learning activities. As students understand their learning style, \\
they will be able to integrate it into their learning process. Kolb Learning Style was the \\
learning style that was widely used based on the theory of learning experiences. Therefore, \\
this study aimed to describe engineering and non-engineering students' learning style. The \\
survey research design with a quantitative approach was applied in this study. A total of 300 \\
respondents were selected randomly from all faculties in Universiti Tun Hussein Onn \\
Malaysia. The survey questionnaire consisted of two main sections representing Learning \\
Goals, Learning Style, and Learning Activities. The result explains that both engineering \\
and non-engineering students are more dominant to adopt the Accommodator learning \\
style, followed by the Converger learning style, and then Assimilator learning style and \\
Diverger learning style. It is concluded that the engineering and non-engineering students \\
are more incline to be a kinesthetic learner. These learning preferences and learning styles \\
will contribute to their engagement in the concept of learning and for educators to plan \\
teaching strategies.
\end{tabular}

\section{Introduction}

Learning about students' learning styles can be very beneficial for both teachers and students. Involving students in the active learning phase necessitates recognizing and comprehending learners' learning styles and teachers' teaching styles. Types of learning play a considerable role in learners' lives. Students may incorporate their learning style into their learning process as they become more aware of it. Students learn in various ways, and teachers must design their courses according to different types of learning. Learning skills, creativity and life and career skills are evidence that students master the process of capability and development, integration and knowledge assessment from different subjects and sources of understanding [1]. Identifying students' learning styles will help educators plan their teaching methods and activities effectively to achieve their learning outcome [2]. The learning style of students is $f$ the supporting forms of active learning [3]. The style of learning plays an important role in ensuring that the learning process is performed effectively.

\footnotetext{
"Corresponding Author: Mimi IMohaffyza, mimi@uthm.edu.my
}

Students should have 21 st-century skills, especially soft skills, to enhance their employability and values. [4]. Universities must make vital elements of education to conduct learning by introducing effective student learning processes in the growth of international education in the formulation of skills in the twentyfirst century. [5]. To ensure that all students receive knowledge from the learning process, educators must observe and consider the discrepancies and similarities between students and use the knowledge to prepare for the learning process [6] to design learning regardless of the learning style of the students [7]. To compare learning style preferences between engineering and nonengineering students in Malaysia, this study used a measurement method called the Kolb Learning Style Inventory (LSI) since LSI is able to provide a simple validation of the Experiential Learning Theory.

\subsection{Kolb Learning Style}

The Experiential Learning Theory of Kolb forms the basis of the paradigm of Kolb's learning style. Experiential learning, which is distinct from other cognitive learning theories, notes the increase in learning process interactions [8]. The Kolb Learning Style Inventory (LSI) is one method for measuring learners' 
preferential teaching style. Kolb's learning style, or more generally known as Experiential Learning Theory (ELT), describes learning as a process in which information is created by transforming experience [9]. Learning is a process, according to $\mathrm{Kolb}$, and knowledge is the transformation of experience [10]. Kolb also indicates that, to have a complete learning experience, students must go through all four phases of the learning cycle, as depicted in Figure 1. These four stages not only allow students to explore a subject through various activities and viewpoints thoroughly, but they also accommodate different learning styles.

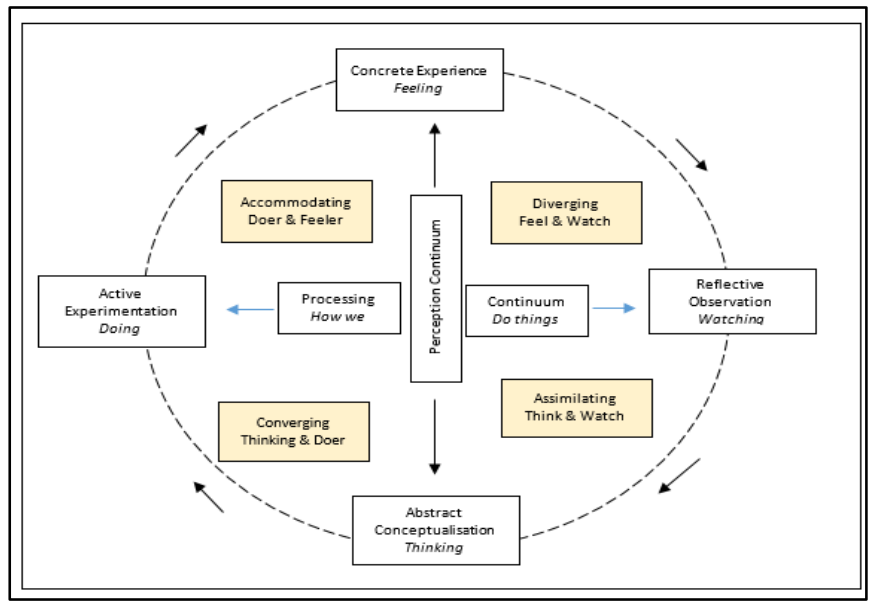

Figure 1: The Learning Model of Experiential Learning at Kolb's Learning Styles

In the Kolb view, learning styles refer to processes in which the person organizes the ideas, rules and principles that address them in dealing with new situations. In practice, one of the most powerful methods in the learning analysis of the individual is the theory of the Kolb learning style. The learning styles as a collection of values, interests, and habits that people attempt to learn about a particular situation by using it [11]. Previous research put it another way: the learner first conducts an action (concrete experience), then tries to think about it (reflective observation), then develops a hypothesis (abstract conceptualization), and finally attempts to exempt it (active experimentation) [12]. According to Kolb, experiential learning can be used in both engineering and non-engineering educational environments [13]. It enables students to participate actively in the learning process to develop awareness, skills, values, and attitudes through direct experience. The learning stages will promote knowledge transfer by providing direct practice tailored to student expertise's scope [14]. This learning method enables students to create their awareness and experience and the acquisition of new skills and knowledge. It stresses that learners learn to use their expertise and experience to solve their problems. This study aimed to compare the preferential learning styles of engineering and non-engineering students in Malaysia by using a Kolb Learning Style Inventory (LSI) model as a reference model because it can provide a basic foundation for validating the theory of experiential learning.

\section{Learning Style in Technical and Vocational Education}

Technical and Vocational Education is an important road to vocational education and the growth of skills. To meet Malaysia's economic needs, the country's TVET enrollment must be increased by 2.5 times by 2025. Transformation Programme [15]. The human resources to meet this demand, however are inadequate. Right at the time. Moreover, TVET is regarded to be less appealing than traditional university education. This has led to a shortage of, especially highly skilled, TVET students. Malaysia must therefore move from the commonly accepted assumption that the only career path for Malaysian youth is traditional university education, and also emphasize TVET as a valid higher education choice.

Technical and Vocational education students are exposed to an educational system aimed at getting a job. (1) A component of an educational activity aimed at providing the necessary knowledge and skills to carry out a specific job, occupation or professional activity in the labour market can be technical and vocational education. At the same time, other types of education, by training people not only as workers but also as citizens, act as an additional form; (2) an activity associated with the technology transition, innovation, and growth processes Knowledge and skills must be transferred since they form the foundation of technical progress and growth [16]. In technical and vocational teaching, as in many fields of knowledge, it is important to identify and understand students differences to adopt the institute's needs to best suit the students' learning conditions and skills. A fact in the classroom, which can be seen in actual scenarios or in virtual techniques, is the need to adapt teaching methods to student learning styles and interests.

If learning styles are not identified, they may influence the teaching and learning process [17]. A lack of knowledge of the modes of learning can also be problematic. In the implementation among students of the acceptable and successful learning styles [18]. Academic success will be impaired as a result [19]. Unfortunately, teacher-centred learning sessions are held by most educators, allowing fewer students to engage in the process and activities of learning [17]. Therefore, for the performance of students, learning style is an important matter. The style of learning will ensure that a learner learns well [19]. Students need to identify their learning styles to build on their learning skills and expand their learning skills. By posing a challenge or using various education methods, educators are also expected to encourage their students to identify their learning style. [20].

\section{Material and Method}

The survey research design with a quantitative approach was applied in this research. A set of questions was designed based on the collected learning style and activities found in literature based on the Kolb Learning Style Inventory. A total of 300 respondents were randomly selected from all faculties in Universiti Tun Hussein Onn Malaysia, UTHM (i.e. Faculty of Civil Engineering and Built Environment, Faculty of Technology Management and Business, Faculty of Technical and Vocational Education, Faculty of Electrical and Electronic Engineering, Faculty of Computer Science and Information Technology, Faculty of Applied Sciences and Technology and Faculty of Engineering Technology). The survey questionnaire consisted of two main sections representing the Learning Goals, Learning Style and Learning Activities. This questionnaire was deployed online from the university's online forum and platform. Respondents 
were able to complete the questionnaire in approximately 10-15 minutes.

\section{Finding and Discussion}

The findings discussed are based on the data of the Learning Goals, Learning Style and Learning Activities items that were constructed. Data that had been collected were used to analyze in the context of Learning Style characteristics, and T-test was conducted to determine whether there are any variations between the two groups of fields, as well as descriptive statistics such as frequency and percentage, to evaluate and interpret the results in this report. The interpretation in the research instrument was used to explain the frequencies and percentages. The agreement level was used to assess the students' perceptions in both areas, which were either Yes or No.

\subsection{The Learning Style Between Engineering and Non- Engineering Students (Descriptive Results)}

Based on a survey conducted, the different learning styles of engineering and non-engineering students were gathered and divided into four forms of learning style defined by Kolb, following the learning style Diverger, Assimilator, Converger and Accommodator. To better understand both of these learning styles, it should be understood that the Assimilator learning style (think and watch) is a variation of Reflective Observation (RO) and Abstract Conceptualization (AC).Converger learning (think and do) is a synthesis of Abstract Conceptualization (AC) and Active Exploration (AE) (AE). Accommodation learning style (feel and do) is a combination of Active Experimentation (AE) and Concrete Experience (CE) and Diverger learning style (feel and watch) is a combination of Concrete Experience (CE) and Reflective Observation (RO) [21]. The percentage of students' data distribution on each Kolb learning style determined by The Kolb Learning Style Inventory is shown in Table 1 and illustrated in Figure 2 below.

Table 1: Results of Learning Style in Vocational Education between Malaysian engineering and non-engineering students

\begin{tabular}{|c|c|c|c|c|c|c|c|c|c|c|}
\hline \multirow[t]{3}{*}{ Field } & \multicolumn{10}{|c|}{ Kolb Learning Style } \\
\hline & \multicolumn{2}{|c|}{$\begin{array}{c}\text { Conver } \\
\text { ger }\end{array}$} & \multicolumn{2}{|c|}{$\begin{array}{c}\text { Assimila } \\
\text { tor }\end{array}$} & \multicolumn{2}{|c|}{$\begin{array}{c}\text { Accomod } \\
\text { ator }\end{array}$} & \multicolumn{2}{|c|}{$\begin{array}{c}\text { Diverge } \\
\mathrm{r}\end{array}$} & \multicolumn{2}{|c|}{ Total } \\
\hline & $f$ & $\%$ & $f$ & $\%$ & $f$ & $\%$ & $f$ & $\%$ & $f$ & $\%$ \\
\hline $\begin{array}{l}\text { Enginee } \\
\text { ring }\end{array}$ & 42 & 28 & $\begin{array}{l}2 \\
9 \\
\end{array}$ & $\begin{array}{c}19 . \\
3\end{array}$ & 51 & 34 & $\begin{array}{l}2 \\
8 \\
\end{array}$ & $\begin{array}{c}18 . \\
7\end{array}$ & $\begin{array}{c}15 \\
0 \\
\end{array}$ & $\begin{array}{c}10 \\
0\end{array}$ \\
\hline $\begin{array}{l}\text { Non- } \\
\text { Enginee } \\
\text { ring }\end{array}$ & 51 & 34 & $\begin{array}{l}2 \\
1\end{array}$ & 14 & 60 & 40 & $\begin{array}{l}1 \\
8\end{array}$ & 12 & $\begin{array}{c}15 \\
0\end{array}$ & $\begin{array}{c}10 \\
0\end{array}$ \\
\hline
\end{tabular}

The results show that Accommodator learning style in engineering students is the highest percentage than others learning style with value $(f=51,34 \%)$ followed by Converger $(f$ $=42,28 \%)$ and Assimilator $(f=29,19.3 \%)$. While Diverger learning styles shows the lowest percentage within engineering students with values $(f=28,18.7 \%)$. Other than that, a similar condition was shown by non-engineering students where the Accommodator learning style shows the highest worth percentage $(f=60,40 \%)$ followed by Converger $(f=51,34 \%)$ and Assimilator $(f=21,14 \%)$. While the lowest value of percentage is Diverger which is $(f=18,12 \%)$.
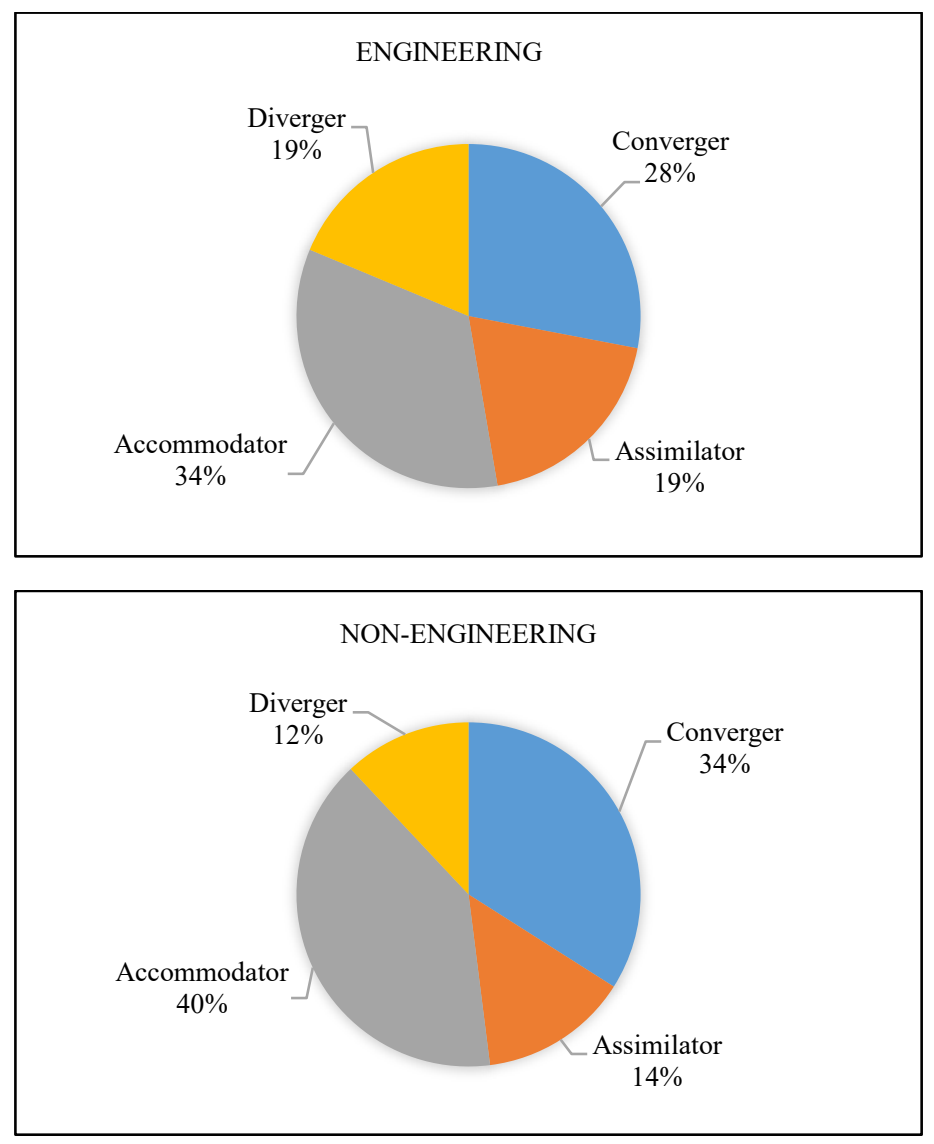

Figure 2: Results of Learning Style in Vocational Education between Malaysian engineering and non-engineering students

The findings of the study can be seen more clearly by referring to figure 3 below where you can see the significant differences between the four learning styles. Although there is a percentage difference between the two fields, it shows that most of the engineering and non-engineering students can be described as an accommodator, which indicates they are most potent in Concrete Experience and Active Experimentation. Instead of logic, they rely on intuition which prefers learning from personal experience, relies on given knowledge rather than carrying out his/her research, requires a clear explanation before starting work [22]. It also shows that both engineering and non-engineering students have strengths that lie in their desire to execute plans and tasks to take part in new events [23]. This result is in line with the Kolb Learning Styles trend, which states that students who use the Doer and Feeler learning styles are best suited for teaching, technician, and engineering jobs and have a background in education, technical studies, and engineering [24].

Other than that, the overall result shows Converger is the second-highest percentage for both fields. In contrast to engineering students, non-engineering students prefer technical tasks and better interpret complex concepts and hypotheses. They also enjoy experimenting. This type of learning style's strengths 
lie in their ability to set goals, solve problems, and make decisions [23].

Apart from that, Assimilator shows the third-highest percentage for both engineering and non-engineering fields. The results show that engineering students have a higher percentage than non-engineering students. This means that engineering student who learns in this style has a wide range of knowledge and arrange it in the most logical way [22] compared to nonengineering students. It also indicates that these students prefer rational, factual, and well-thought-through knowledge [24]. The strengths of this learning style lie in their ability to schedule, coordinate, evaluate and engage in inductive reasoning systematically. The results of this study are confirmed by a study conducted by [25] in which engineering students need more diverse knowledge gathered from different sources since they must observe how to execute the task before beginning to perform it. The knowledge is presented from different angles and concluded in a logical, simple, and concise manner. Finally, the type of learning that shows the fourth-highest percentage for both engineering and non-engineering is Diverger. The findings showed that there was a higher proportion of engineering students compare to non-engineering students. It indicates that engineering students with a particular style of learning observe a situation and then look at the situation later from multiple viewpoints, learning from each one [22]. Besides, it also shows that engineering students have more effective at seeing a particular situation from different perspectives than nonengineering students [26].

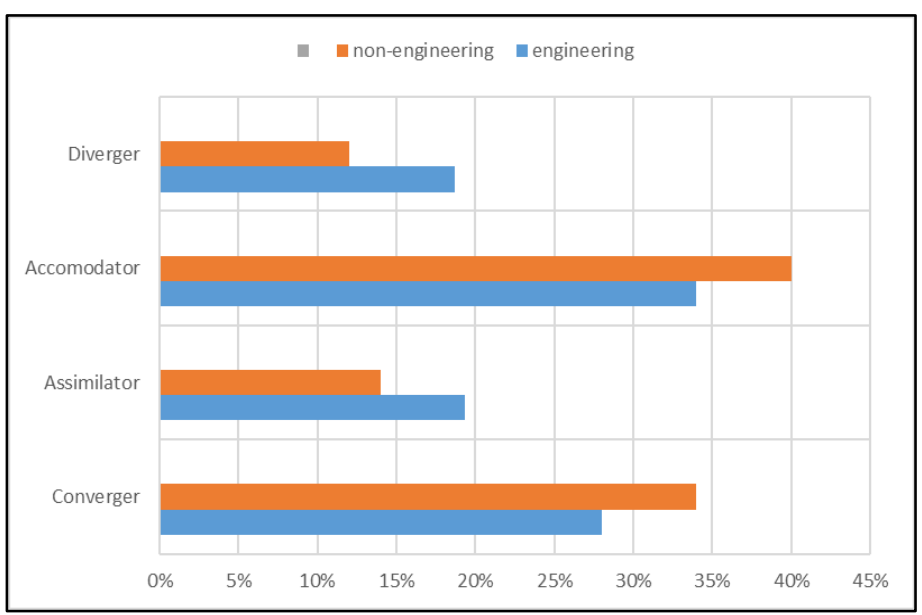

Figure 3:Comparison of Learning Style in Vocational Education between Malaysian engineering and non-engineering students

Because of the interest in designing the learning process, educators have to consider the style of learning of different students. Other than that, to maximize learning effectiveness, the learning method that relates to each learning style is more important because the learning method has a learning style related to it [27]. The difference between the way information was obtained and interpreted was more related to the style of learning that students had. One of the key reasons for gathering learning efficacy is the type of learning [21]. The suggest that knowledge of the learning styles of learners can be important for curriculum and teaching improvement. Similarly, [28] state that If the learning styles of students are evaluated, it is possible to systematically plan learning activities that further strengthen strengths or develop weaker phases to maximize thinking and problem-solving skills."

\subsection{Comparison of Learning Style Between Engineering and Non-Engineering Students (Inferential Results)}

As for the comparison between Engineering and NonEngineering students, the inference analysis had shown a nonsignificant value between both groups in practising learning style in their learning process with mean and significant value (Engineering $=0.538$, Non-Engineering $=0.562, \mathrm{p}=0.543$ ). Although there is a difference in percentage and frequency values, the inference value indicates no significant value for engineering and non-engineering students learning style. This shows that both groups of students have approximately the same learning style between engineering and non-engineering students.

Table 2: The Differences of Learning Style Between Engineering and NonEngineering Students

\begin{tabular}{|c|c|c|c|}
\hline Field & Mean & Std Deviation & Significant \\
\hline Engineering & 0.538 & 0.133 & \multirow{2}{*}{0.543} \\
\hline Non-Engineering & 0.562 & 0.130 & \\
\hline
\end{tabular}

\section{Conclusion}

The study showed that learning styles are necessary for a course to achieve total value from learning. While sharing certain characteristics, may show major differences in other aspects that affect learning. Educators who are mindful of these differences and can articulate these characteristics have a better chance of creating good instruction for a wide range of learners. In knowing their strengths and interests and utilizing the learning cycle, all learning styles will become stronger for students exposed to learning style models and Kolb's Learning Style Inventory (LSI), which will enable them to become more active learners. This research can be very beneficial for educators who want to increase the effectiveness of the learning process. Recognizing and reacting to individual learning styles may improve students' ability to accept and retrain content and help to avoid possible learning difficulties by selecting the appropriate teaching method. This may also aid in selecting the most suitable materials and activities for the individual students.

\section{Acknowledgement}

We would like to thank the team of Project Matching Grant K135 who participated in this study consisting of experts from two universities, Tun Hussein Onn University, namely Maizam Alias, Tee Tze Kiong, Lee Ming Foong and Faizal Amin Nur Yunus and Universitas Negeri Paandg, namely Ganefri, Nizwardi Jalinus, Syahril, Sukardi, Risfendra and Rahmat Azis Nabawi for their contribution. Finally, we would like to thank the Tun Hussein Onn University of Malaysia for the financial support under UTHM Grant Vot U940. 


\section{References}

[1] M.C. Sahin, "Instructional design principles for 21 st century learning skills," 1(1), $1464-1468$,

2009 , https://doi.org/10.1016/j.sbspro.2009.01.258

[2] S.Kalbasi, M.Naseri, G.H.Sharifzadeh, A.Poursafar, "Medical students' learning styles in Birjand University of medical sciences strides in development of medical education," Journal of Medical Education Development Center of Kerman University of Medical Sciences, 2008, 1(5): 10-16. doi: $10.5681 /$ rdme.2013.017

[3] Kolb, Y,Alice, \& D.A. Kolb, "The Kolb Learning Style Inventory Version 3,” 2005, Technical Specifications. Experience Based Learning Systems, Inc.

[4] N. Azid, R. Rawian, Shaik-Abdullah \& T.K. Tee, " The Development of Interactive Case-Based Smart Thinking and Industrial Problem-Solving Stimulator to Enhance TVET students' Thinking Skills," Journal of Engineering Science and Technology, 2019, 14(5), 2643-2656.

[5] A. Halstead \& L. Martin, "Learning styles: A tool for selecting students for group work," International Journal of Electrical Engineering Education, 39(3), 245-2522, 2002. https://doi.org/10.7227/ijeee.39.3.8

[6] R. Laura, "What is differentiated instruction? New York: Rowan University,"2007. https://doi.org/10.1093/ww/9780199540884.013.u28949 $\underline{2}$

[7] C. Weselby, "What is differentiated instruction? Examples of how differentiated instruction in the classroom," Oregon: Concodia University, 2017. https://doi.org/10.4135/9781483346243.n103

[8] S. Cassidy, "Learning styles: An overview of theories, models, and measures," Educational 2004. https://doi.org/10.1080/0144341042000228834

[9] Y.M. Yousafzai, N.Baseer, S.Fatima, A.Ali \& I.Shah, I. "Investigating the Relationship between Learning Styles and ESP Reading Strategies in Academic Setting," International Journal of Applied Linguistics \& $\begin{array}{llll}\text { English } & \text { Literature, } & \text { 7(3). } & 11-115,\end{array}$ https://doi.org/10.7575/aiac.ijalel.v.7n.3p.156

[10] C.Babadoğan, C. "Öğrenme Stilleriyle İlgili Araştırmaların Taranması (Survey of Researches Related to Learning Styles) Eğitim Bilimleri Dergisi," Ankara Üniversitesi, 24(2), 603-606, 1991.

[11] T. De Jong, "Cognitive load theory, educational research, and instructional design: some food for thought," Instructional science. 38(2): 34105, 2010. https://doi.org/10.1007/s11251-009-9110-0

[12] A. Z. Moghadam, M.M. Fard "Surveying the Effect of Metacognitive Education on the on the Mathematics Achievement of 1st Grade High Junior School Female Students in Educational District 5, Tehran City, 2009-10 Educational Year, Procedia-Social and Behavioral Sciences, 29(15):31-40, 2011. https://doi.org/10.1016/j.sbspro.2011.11.394

[13] C. Tseng, "Connecting Self-directed Learning with Entrepreneurial Learning to Entrepreneurial Performance," International Journal of Entrepreneurial Behavior and Research, 19(4), 425- 446, 2013. https://doi.org/10.1108/ijebr-08-2011-0086

[14] Dumiyati, "Pendekatan Experiential learning dalam Perkuliahan Kewirausahaan di Perguruan Tinggi untuk Menghadapi Asean Economic Community [Suatu Kajian Teoretis]," Prosiding Seminar Nasional Profesionalisme Pendidik dalam Dinamika Kurikulum Pendidikan di Indonesia pada Era MEA, 87- 97, 2015

[15] Ministry of Education Executive Summary Malaysia Education Blueprint 2015-2025, 2015.(Higher Education).

[16] O.O.Oskay, E.Erdem, B.Akkoyunlu, A.Yilmaz, "Prospective chemistry teachers' learning styles and learning preferences," Procedia Social and

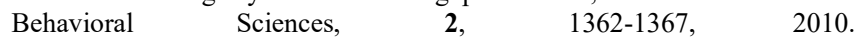
https://doi.org/10.1016/j.sbspro.2010.03.201

[17] M.H. Yee, J. Yunos, W.Othman, R. Hassan, T.K.Tee, \& M. Mohamad, "Disparity of Learning Styles and Higher Order Thinking Skills among Technical Students," Procedia - Social and Behavioral Sciences, 204( 2014), 143-152, 2015. https://doi.org/10.1016/j.sbspro.2015.08.127

[18] H.Pashler, M.McAndiel, D.Rohrer, \& R.Bjork, "Learning styles: Concepts and evidence," Psychological Science in the Public Interest, 2009.https://doi.org/10.1111/j.1539-6053.2009.01038.x

[19] I.J. McCoog, "21st Century teaching and learning. Education Resource Center," 2018.

[20] E. Marin, "Experiential learning: empowering students to take control of their learning by engaging them in an interactive course simulation environment," Procedia - Social and Behavioral Sciences 180, 854 859, 2015. https://doi.org/10.1016/j.sbspro.2015.02.224
[21] A. Y. Kolb \& D.A. Kolb, “Experimental Learning Theory Bibliography," Cleveland: OH : Experience Based Learning System Inc, $2003 \mathrm{https://doi.org/10.1007/978-1-4419-1428-6} 227$

[22] M. MiMuro, A, Terry, “A matter of style: Applying Kolb's learning style model to college mathematics teaching practices," Journal of College Reading and Learning, 38 (1), 53-60, 2007. https://doi.org/10.1080/10790195.2007.10850204

[23] E.F. Turesky \& D. Gallagher, "thyself: Coaching for leadership using Kolb's experiential learning theory," Coaching Psychologist, 7(1), 5-14, 2015.

[24] D.A. Kolb, "Learning Style Inventory: Self Scoring Inventory and Interpretation Booklet," McBer and Company, Boston, 2005. https://doi.org/10.1007/978-3-8350-9212-9_4

[25] M.N. Ghufron \& R. Risnawita, "Gaya Belajar: Kajian Teoritik," Yogyakarta: Pustaka Pelajar.

[26] S. Nasution, "Berbagai Pendekatan dalam Proses Belajar and Mengajar," Jakarta: Bumi Aksara. 2009.

[27] Ö. Şimșek, "Marmara Öğrenme Stilleri Ölçeğiienin Geliștirilmesi Ve 911 Yaş Çocuklarının Öğrenme Stillerinin İncelenmesi," Marmara Üniversitesi Eğitim Bilimler Enstitüsü. İlköğretim Anabilim Dalı. Yayınlanmamış Doktora Tezi. 2019. İstanbul

[28] J.A.Gyeong \& S.Y. Myung, "Critical thinking and learning styles of nursing students at the baccalaureate nursing program in Korea," Contemporary Nurse, 29(1), 100-109, 2008. https://doi.org/10.5172/conu.673.29.1.100 